(7)

\title{
Cultivation of Fear Through Media: Analysis to Reveal Relationship between Perception about COVID 19 and Socio-economic Background of Media Consumers
}

\author{
${ }^{a}$ Samia Manzoor, ${ }^{\text {b Aasima Safdar }}$ \\ ${ }^{a}$ Assistant Professor of Communication Studies, Bahauddin Zakariya University, Multan, Pakistan \\ Email: samia.manzoor@bzu.edu.pk \\ ${ }^{\mathrm{b}}$ Assistant Professor of Communication Studies, Bahauddin Zakariya University, Multan, Pakistan
}

\begin{abstract}
ARTICLE DETAILS
ABSTRACT

History:

Accepted: 29 April 2020

Available Online: 15 June 2020

\section{Keywords:}

COVID-19, Cultivation Theory,

Fear, Social Media, Socio-

Economic Backgrounds, Upper,

Middle and Lower Class

JEL Classification:

I19, M14, M19, O17

DOI: $10.47067 /$ reads.v6i2.198

COVID-19 is the pandemic that has been experienced by the whole world presently. The present research sought to explore how media is cultivating fear among heavy and light users of upper, middle, and lower socio-economic background. Theoretical support for the present research was taken from the theory of cultivation analysis. Twenty-one residents of Multan belonging to upper, middle and lower socio-economic background were selected through snowball sampling technique and interviewed through WhatsApp by the researchers. The interview data was analyzed through NVIVO 10. Eight themes emerged out of the interview data and it was observed that media was cultivating fear among the users of upper and middle socio-economic backgrounds as they were using media for longer periods of time while media users of lower socio-economic background were not very fearful of this pandemic. The results supported that media has strong cultivation effects regarding COVID-19.
\end{abstract}

(C) 2020 The authors. Published by SPCRD Global Publishing. This is an open access article under the Creative Commons Attribution-NonCommercial 4.0

Corresponding author's email address: samia.manzoor@bzu.edu.pk

\section{Introduction}

COVID-19 has become one of the most threatening issues which the mankind is facing during recent years. This pandemic has created such fear in the minds of people that they have started to commit suicides (Mamun \& Griffiths, 2020). There is no doubt about it that there are no humans left around the globe who are unaware about this deadly virus.

Media is playing a pivotal role in providing information about current situations to the public. So much so that governments are using channels of social media and television to provide awareness to the public about COVID-19 (Ait Addi, Benksim, Amine, \& Cherkaoui, 2020). Traditional and social both types of media outlets are taking this responsibility upon themselves to educate people about COVID-19 and the related issues. Especially in a country like Pakistan where the literacy rate is low (Rehman, Jingdong, \& Hussain, 2015) and a great majority of people live in remote areas (Shahzad, Zahid, ur Rashid, Rehan, Ali, \& Ahmad, 2017), media has become an even more significant role player in the 


\section{Review of Economics and Development Studies, Vol. 6 (2) 2020, 217-228}

provision of information to the people belonging to all kinds of socio-economic backgrounds. This assumption also stands true that when media informs people about some crisis, sometimes it infuse a fearsome emotion in them (Altheide, 2002).

The present research aimed to explore the perceptions of people belonging to three major socioeconomic backgrounds in Pakistan i.e. lower class, middle class and upper class. Relationship between their media use time and their perception about COVID-19 pandemic was developed. George Gerbner assumed that media has strong cultivation effects (Baran \& Davis, 2011). Following the footsteps of Gerbner $(1969,1970)$ it was tried to find out that how the media were cultivating the minds of users about COVID-19, how the cultivation effect is different for people of different socio-economic backgrounds and for heavy and light users of media?

\section{Literature Review}

It has been confirmed by literature that whenever some pandemic occurs mass media provides information in a very alarming and threatening way (Bomlitz \& Brezis, 2008). When people receive this information through mass media they become fearful and frightened (Alcabes, 2009). Fear of the disease among people plays an important role in giving significance to the disease by them (Setbon \& Raude, 2010; Altheide \& Michalowski, 1999). Mesch, Schwirian, \& Kolobov, (2013) conducted research on media use of people and their fear of getting infecting by H1N1. It was observed that people who used media for longer periods of time were more fearful. They further observed that as time passes people lost interest in information regarding the disease.

Hansen (2009) observed the presentation of SARS in Norwegian media and observed that this disease received a lot of media attention in Norway and thus created enormous fear in the public. Fear of SARS faced by the public developed hurdles in provision of medical facilities to them. Ahorsu, Lin, Imani, Saffari, Griffiths, \& Pakpour, (2020) developed a seven- item scale to measure the worry and fear of people due to COVIA-19 and suggested ways to overcome fear. They said that during the outbreak of infectious diseases people's psychological reactions become negative.

Grupp (2003) wrote that fears are planted and cultivated by media. She added that fears are least cultivated through direct exposure. In her opinion the world has moved from a "fearsome life towards a life with fearsome media". Studies on fear have confirmed that the element of fear in everyday life has increased. A very important contributor of increasing fear in the society is the stories presented by media (Furedi, 2007). Llewellyn (2020) said that it is extremely important for people to understand the psychology of social media information only then we can avoid disinformation especially in crisis situations like the one the world is facing presently in the form of COVID-19.

Van den Bulck \& Custers (2009) found in a research on $\mathrm{H}_{5} \mathrm{~N} 1$ that fear of a pandemic comes first than the actual pandemic. They further confirmed that exposure to television is strongly related to the increase in the fear of disease. Ball-Rokeach \& DeFleur (1976) confirmed that during a crisis people rely more on media. Garfin, Silver, \& Holman (2020) conducted research on COVID-19 regarding public health risk and media exposure and confirmed that people who use media for longer periods of time become more fearful of the disease.

Theoretical support for the present research was taken from theory of cultivation analysis presented by George Gerbner. This theory states that "those who spend more time watching TV are more likely to perceive the real world in ways that reflect the most common and recurrent messages of the television world, compared to people who watch less television but are otherwise comparable in 


\section{Review of Economics and Development Studies, Vol. 6 (2) 2020, 217-228}

terms of important demographic characteristics" (p. 4). Cultivation theory further proposes that when an individual exposes himself to media content for longer periods of time they start living in a media reality that is actually not based on facts but just media content (Tony, 2000). In fact this influence goes to such an extent that their views and perception about reality become totally based on what they repeatedly see and hear on media. Cultivation occurs in two ways. One is mainstreaming, it happens when similar kind of content is shown on different media channels. For viewers these symbols and messages become more influential as compared to the other sources of information and thus they start thinking the way media guides them (Baron \& Davis, 2003). The second way of cultivation is resonance, it occurs when media depiction of reality is supported by the real world incidents. Resonance is when, what we see on media is reinforced by the real world experiences. This gives the audience a "double dose" that results in an increase in the cultivation effects (Baron \& Davis, 2003).

Through the present research the researchers intend to know how much fear is cultivated through media in the people of different socio-economic backgrounds of Pakistani society. This will open a new line of research, because whatever content Pakistani media is showing about COVID-19 pandemic is likely to have cultivation effects on the viewers. The present research helped to find out difference of cultivation effect in the people of different socio-economic backgrounds i.e. upper class, middle class and lower class about COVID-19. What were the thoughts and opinions of public about this pandemic based on the information they were taking from media.

Jordan (1992) and Yardi \& Bruckman (2012, May) conducted researches to identify relationship between ideologies of time and mass media use within the family system and comparison between middle to upper class white American parents and low income urban African American parents to know about how each group use technology respectively. This shows that previously researches have been conducted in the field of media studies by taking socio-economic status as a key variable. But it would be unique to find out that how media is cultivating fear regarding COVID-19 among the heavy and light viewers of different socio-economic backgrounds.

\section{Method}

The present research employed qualitative approach. Qualitative design has characteristics to describe the issue with rich details. Denzin (1994) wrote that qualitative research involved many methods such as interpretative, naturalistic techniques for exploring the phenomenon. It helped the researcher to conduct the research in a natural setting and the researchers could explore the holistic picture of the phenomenon by analyzing words, reports, photos and information (Creswell, 1994).

For data collection, the researchers employed technique of in-depth interviews. It helped the researchers to analyze similar or different viewpoints of the informants about the issue at hand (Rubin \& Rubin, 1995). The idea of qualitative interviews was to understand the thinking of interviewees (Kvale, 1996) and what are their original thoughts. Interviews were just like direct conversation (Lofland \& Lofland, 1995) and a comprehensive interview gives detailed information about the topic from the interviewee who had pertinent knowledge (Charmaz, 2006).

\subsection{Sample for the study}

For the present study, twenty one informants were selected from different socio-economic backgrounds. Seven informants were selected each socio-economic background i.e. upper, middle and lower class. Upper class could be defined as a group of people who are well educated, own business, earn more than their needs, have very safe future in terms of finances and they enjoy luxuries. Middle class is defined as a group of people who possess high level of education, professional skills and a 
Review of Economics and Development Studies, Vol. 6 (2) 2020, 217-228

relatively stable and high income (Wang, 2009). They usually lack luxuries but they enjoy a stable life style. Lower class is the people who face difficulty to make ends meet. They usually have scarce finances. Usually they don't have higher levels of education. They live life with limited resources with no choice of luxuries. These interviews were conducted from the residents of the city of Multan by using the technique of snow ball sampling. As Berg (1988) referred that in snow ball technique, the contacts were developed by the recommendation of people who were already in circle. The interviews were taken during the month of March 2020. Researchers asked the informants about their consumption patterns of media and their perspective COVID-19 crisis. The interviews were originally conducted in Urdu language and afterwards were transcribed in English language

\subsection{Data analysis}

For the curent study, three types of coding were employed i.e. open coding, axial coding and selective coding (Strauss \& Corbin, 1998). Open coding classified and labelled the phenomenon as pointed by the data. The text was read line by line and was broken down into different codes. Open coding moved towards to compare codes where similar codes were put together under same conceptual label. In this way each group became a concept (Strauss \& Corbin, 1998).

During axial coding the data was analyzed again by making associations between categories and its subcategories (Strauss \& Corbin, 1998). The analysis explained the phenomenon implanted in the data. In the last step, the selective coding integrated the categories to a structure or theoretical framework. In this case, first step was to identify core category.

For the data analysis purpose the researchers used NVIVO 10. In the process of open coding, the researchers put data into numerous nodes of NVIVO 10 software. In second steps, the researchers made connection with different codes and developed categories. In selective coding, the researchers carefully read all the categories and developed themes from the data. These themes answered the research questions at hand.

\subsection{Findings}

Twenty one interviews were conducted for the present research, from informants belonging to upper, middle and lower socio-economic backgrounds. Seven interviews were conducted from each socio-economic group. The informants from upper class were highly educated and mostly heavy consumers of media. They mostly used media for four to five hours on daily basis. They consumed not only Pakistani media, but foreign news channels, news apps, social media and different news websites.

The informants from middle were also mostly heavy consumers of media. They reported three to four hours of media use. They mostly watched Pakistani electronic channels and used social media. They also relied on information received from their peer group. However, the informant from lower class used media approximately two to three hours daily. Their main sources of information were television, radio and peer group. Few informants from lower class replied that they consider their friends and family members more reliable sources of information as compared to media. 
Following themes emerged after analyzing the data from the informants:

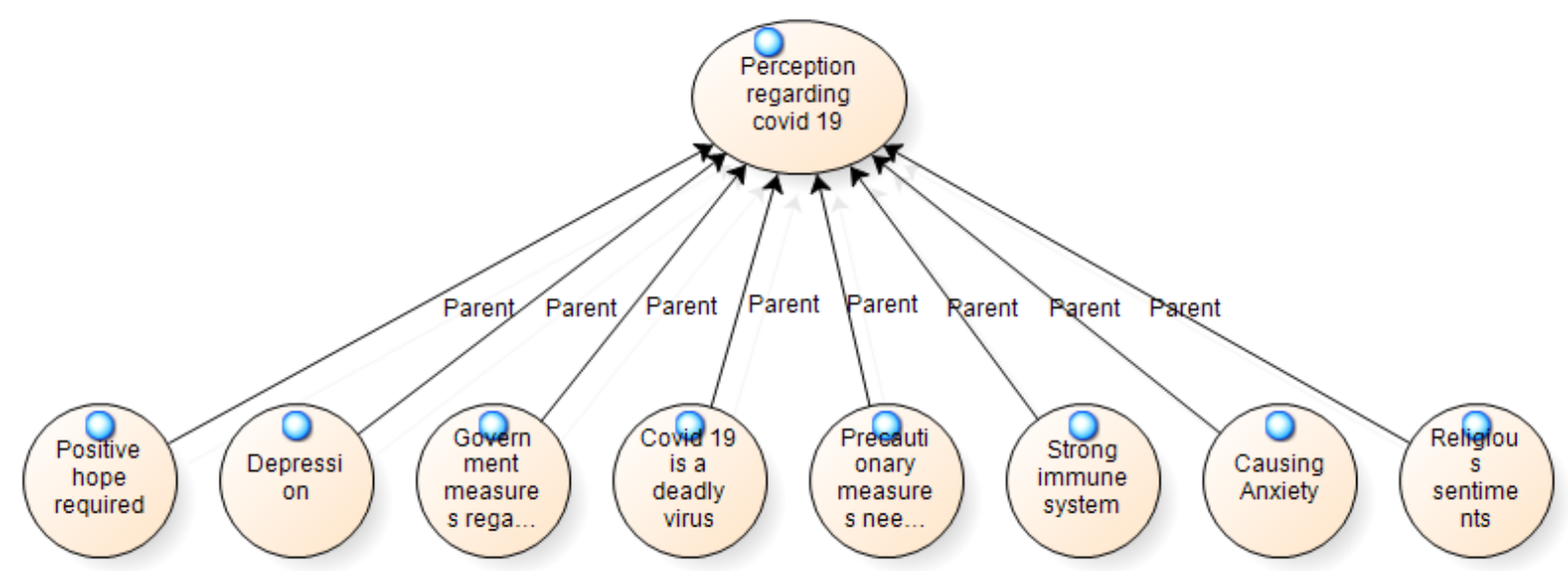

NVIVO 10 Model for Perception regarding COVID-19

\section{i. COVID-19 Is a Deadly Virus}

The first theme emerged from data was that COVID-19 is a deadly virus. The informants from upper and middle class were of the opinion that it could not be easily cured. It could be easily transmitted through touch and contact. It was started from animals and it had affected one forth human population of the world. There was a possibility that out of every 100 people, 3 to 4 people could be affected with this virus. There was no cure available right now. Only those people have survived from this that had strong immune system. It was more dangerous for old people and people with weak immune system. Until, the vaccine was made it is a greater threat for human beings.

Although government and doctors have suggested maintaining social distancing and self-isolation to combat the virus but it is very difficult to get themselves isolated. People had to perform different duties on daily basis. The question was for how long they could be isolated. The virus is very dangerous. It could only be treated if the patient is diagnosed at early stages. In later stage it affects respiratory system which causes major complications for the victims. The informants were of the opinion that corona virus had caused panic among the society. Media is giving a lot of information that had caused anxiety among the masses. It had changed the life style of people around the world. The virus though emerged in Wuhan, China but now it has spread all over the world. Especially, Western world are badly affected by it. The situation in Pakistan is also getting worse day by day.

However, the informants from lower class commented that corona was not a deadly disease. Not everyone was affected by it. Normal activities are going on. Shops and markets are open and people are working. Few people were affected by it but they were cured. It depends on the fate of individual either he is going to get badly affected by it or not. Even few informants commented that the virus did not exist and it was just a faulty imagination. As one of the informant commented;

"This is in our faddism (weham) that it is deadly."

\section{ii. Causing Anxiety}

People from upper class had mix opinion regarding anxiety and fear factor. Few were of the opinion that corona caused much panic and anxiety. As they started to follow media they became psychological disturbed. They felt corona symptoms among themselves. If they got ill and suffered from sore throat, 


\section{Review of Economics and Development Studies, Vol. 6 (2) 2020, 217-228}

they thought that the virus has affected them until they consulted their doctor. Such fears disturbed their sleeping patterns and regular life. But with the passage of time, the situation got better and they lowered media consumption regarding corona information. They reported that excessive use of media was a main cause of anxiety and fear in them. However, some of them reported that they never experienced any panic because they followed safety measures strictly. They admitted that exposure with corona positive person can create problems for them. Although corona has caused much panic but they believed that not every corona victim dies. People get cured if they received proper medical attention.

The informants from middle class also expressed mixed opinion regarding corona anxiety. Few expressed that sometimes sneezing and other mild symptoms panicked them but soon they overcome this panic. They stressed on taking safety measures. They believed if they were destined to suffer from corona, they could not avoid it. They should not get panicked but should focus to take proper safety measures as suggested by WHO (World Health Organization). They suggested that they have trust in Allah and they believed that hopefully they would not get this virus. As one of the informant commented that:

“No. Never. I don't like to get panicked over nothing. If we have to face it, we will, we cannot avoid it if we are destined to suffer from it. But we must not get ourselves worried over nothing."

However, the informants from lower class were of the opinion that they never got panicked. They believed that it was just a disease which could be cured within few weeks. They were not concern about corona and did not express any fears regarding it. Few were of the opinion that in the start. It was bit frightening but with the passage of time, things got normal. They stressed that they pray to Allah and they have faith that they will be saved. There was nothing to be worried or panicked about.

\section{iii. Depression}

Third theme that emerged from data was depression. It was noticed that informants from upper and middle class expressed their deep concerns regarding Covid 19. However, the informants from lower class were not frightened. As informants from upper and middle class were heavy consumers of traditional media, social media and new media. These extensive sources of information have increased their concerns regarding the disease. On the other hand, little media use and reliance of lower class saved them from anxiety and depression.

Informants from upper and middle class commented that when the corona virus broke out in Pakistan they devoted much time to media for getting information. Media provided them guidance about how to deal with the crisis. But gradually, they started feeling depression. As one of the informants commented that she started thinking that the corona virus would never end. If she gets affected by the virus, how she would be able to save her children. Some of them revealed that due to the stressful situation, they have limited their media use. Instead of watching corona news, they switched their interest towards other entertainment media. The decreased the use of media has made positive effects on them to lessen their stress and worry.

Other informants' believed that it is a deadly virus, which has caused a number of deaths in Western countries. If developed world could not cope with the crisis of corona, how the people in Pakistan could be saved. There is no vaccine available for its treatment. Scientists around the world are working to

find a cure but there is no hope yet. They stressed that due to stress caused by corona virus their routines of life have been disturbed. They did not feel relaxed, happy and comfortable. They felt that now they could not enjoy their lives anymore. Some of them commented that their sleeping patterns 


\section{Review of Economics and Development Studies, Vol. 6 (2) 2020, 217-228}

have also been disturbed. They have this fear that they could be affected by the virus.

\section{iv. Positive Hope Required}

The other theme that was emerged from data was positivity and hope. Although people from all walks of life were disturbed due to this situation but still they had positivity and hope regarding the end of corona virus. The informants from all three socio-economic backgrounds i.e. upper, middle and lower classes expressed positivity and hope regarding it. As one of the informants commented that the virus emerged from Wuhan but now normal activities of life have started there. China was badly affected by the novel corona virus but now they are coming back towards normality in life. Same was the case, in some European countries, the death toll is decreasing. They stressed that we must hope for the best that the sooner or later scientists would find out a cure for COVID-19. As scientist in America, UK, China and other European countries are already working on it. They are also giving good news regarding its cure.

Another informant commented that it is miraculous that Pakistan is not yet badly affected by the corona virus. There are limited cases in Pakistan as compare to the West. The informants stressed that we must believe on Allah, and have faith and everything will be fine in the end. Especially people from middle and lower socio-economic backgrounds stressed that if they will have strong belief on Allah, they would soon be out of this pandemic.

However, the informants from lower class commented that lock down situation had caused hopelessness. Because, now they have no sources of income, they are living on savings; education of children is also getting severely affected. If this situation persists for a long time period, it would create sever economic problems for them.

But overall, the informants were hopeful regarding the end of corona virus and stressed on precautionary measures and belief in Allah.

\section{v. Precautionary Measures Needed}

Another theme that emerged from the data was precautionary measures. The informants from upper class were highly concerned about taking precautionary measures and social distancing. Almost every one told that they are adopting precautionary measures. They stressed that it was very important to wear mask and gloves while going out of home. One of the informants told that she always maintains 2 meter distance from others, she washes her home every day and when she is outside she prefers not to come out of the car and mostly does shopping online. Upper class informants shared that they are in self-quarantine and are adopting healthy life style by avoiding junk food. One of the informants commented that he was a very social person but since the pandemic hit he has started avoiding physically meeting with people and instead have started meeting online. Many of the informants commented that social distancing was quite important because it was the only way through which we can limit the spread of the virus. If one wants to contact with others, one can use mobile, social media or online meeting applications. Few of the informants commented that they are doing their work online and their office meetings are conducted through online meeting applications.

Similarly, the informants from middle class stressed on using face masks, gloves, hand sanitizers and social distancing, as one of the informants commented that:

"I only wash hands when I feel there is a need to. Otherwise when I go outside I use hand 


\section{Review of Economics and Development Studies, Vol. 6 (2) 2020, 217-228}

sanitizer regularly. Every time I disembark from my vehicle to fetch something or to do some chores I immediately apply hand sanitizer as soon as I get back in. I use face mask, hand sanitizer, and avoid going to public places.”

They told that they had limited their outside activities and preferred to stay at home. As one informant commented whenever she buys fruits and vegetable from bazar she cleans the grocery and sanitizes her hands. The informants were of the opinion that media is giving them enough information regarding precautionary measures and they are trying their best to follow these guidelines. A few of the female informants told that they do not even call house help to perform household chores. All members of the family try to participate in household chores. Complete isolation is pertinent to avoid the virus.

However, when it was asked from the lower class informants what precautionary measures they have adopted to avoid corona? It was noted that informants also know about precautionary measures and most of them replied that they are following the guidelines to avoid the virus but it appeared that they were not highly concerned about these measures. As informants from upper and middle class commented that they tried to wash their hands three to four times in an hour while some of the informants from lower class said they wash their hands three to four times a day. Even few commented that there was no need of such precautionary measures and social distancing because they do not consider the virus very serious threat.

Overall, it was noted that the informants from upper and middle class were more concerned about precautionary measures and social distancing than the informants with lower socio-economic background.

\section{vi. $\quad$ Strong Immune System}

Data also revealed that people are concerned about their immune system. The informants from upper class told that through traditional and social media they have come to know that the virus was not dangerous for those who have strong immune system. People with weak immune systems are more vulnerable to this virus. The informants told that they are paying keen attention to boost up their immune system. They are taking healthy diet including fruits, vegetables and vitamin supplements. They have started avoiding junk food and try to take good sleep. It was noted that these informants not only consumed media but other internet sources were also utilized to get information regarding healthy life style and diet plans. The similar opinion was given by the informants from middle class. They stressed on healthy life style and strong immune system. One of the informants commented that it was very difficult to avoid the virus in a country like Pakistan. Only people with strong immune system could survive from it.

However, the informants from lower class were not much aware of immune system. They were of the opinion that they are taking normal diet following their previous routine. They did not share information healthy life style, healthy food or supplements. They were not conscious to explore media to get information regarding special diet plans or medications for avoiding corona virus. They were continuing their normal routine.

\section{vii. Religious Sentiments}

Religious Sentiments was another theme that emerged from the data. The informants from upper class commented that during pandemic they had increased their religious activities because now they have more free time and they are free at home. Some of the informants were of the opinion that there is no change in their religious activities. They are following their previous routines. Few informants were 


\section{Review of Economics and Development Studies, Vol. 6 (2) 2020, 217-228}

of the opinion that the pandemic was from Allah. He was the master planner and He will get human beings out of this problem and they must have faith in Allah and be consistent in their religious activities.

The informants from the middle class were of the opinion that due to pandemic their religious activities had been increased. As one of the informants commented that it's only our strong link with Allah that can save us from this problem. Another informant commented that:

"It can be a punishment by Allah, because when we humans go astray from the right path then He punishes us through such pandemics ..... and as a Muslim I believe that only Allah has the cure of this disease.......Not humans.......I have my faith and belief in Allah so I don't feel depressed.”

The informants stressed that everyone should increase their religious activities by offering prayers regularly and recitation of Holy Quran. They shared that they feel that religious activities give peace of mind and heart and one starts feeling strong.

The informants from the lower class also told that they were praying to Allah to save them from this virus. They also believed that this pandemic could be Allah's wrath so that people can learn a lesson and start following the right path.

Overall, it was noted that the informants from all classes commented that their religious activities have increased and only Allah can save them from this agony. For this reason they have started spending more time and money in religious activities.

viii. Government Actions Regarding COVID-19

Last theme that was observed from data was government activities regarding pandemic. The informants from upper class had mixed opinion about government activities. Some of the informants were of the opinion that Government of Pakistan was doing excellent to control pandemic. The government provided ration and money to the poor families. Along that the government did smart lock down that was good strategy. Because Pakistan was not a developed country, it was very difficult to do complete lockdown in the country. However, some of the informants had quite different opinion regarding government activities. These informants were not satisfied with government measures regarding pandemic. They criticized government policies. They were of the opinion that there should be stricter lockdown because the virus spreads through person to person. Spread of corona virus could only be avoided by implementing complete lockdown.

Most of the informants from middle class supported government strategies to combat corona virus. They were of the opinion that complete lock down could create lot of problems for those people who are economically weak. The government should make effective management system to regulate market and other economic sectors. People must be provided with economic resources. People should be stressed to wear mask compulsorily while going out of home and they should maintain two meters distance from others. Otherwise, the situation in the country could get worsened. As the country health situation was not satisfactory.

However, the informants from lower class were not satisfied with the policies of the government regarding corona virus. They mostly criticized the government. Moreover, they did not support lockdown in the country. They were of the opinion that due to lockdown; poor families were living in very bad conditions. They do not have financial support. If this situation continues it would be very 


\section{Review of Economics and Development Studies, Vol. 6 (2) 2020, 217-228}

difficult for the poor people to survive. Government should make policies to support the people who had limited economic resources.

\section{Discussion and Conclusion}

George Gerbner (1998) defined heavy viewers as those who watch more TV and light viewers as who watch TV for lesser amount of time. According to this definition most of the informants belonging to upper and middle class socio-economic background were heavy users of media while most of the users belonging to lower class socio-economic background were light users of media. The findings of the present research are congruent to the cultivation analysis of George Gerbner. The aim of the current research was to dig out how much fear has been cultivated in the minds of media users about COVID19. In-depth interviews were conducted with twenty one users of media belonging to upper, middle and lower socio-economic backgrounds. The interviews were later analyzed through NVIVO-10 and eight themes emerged from the interview data. It was revealed that users of upper and middle class were very much fearful of COVID-19 while the users of lower class were not. Upper and middle class people reported that corona is an extremely deadly virus, they reported that they corona id causing anxiety and depression among them while the users of lower class opined that this virus is just a myth. They were not depressed of anxious. Media users of upper and middle class were taking lots of precautionary measures including building up their immune system but people of lower class were neither concerned about precautionary measures nor they were well aware about immune system. "Positive hope" was the theme that was present in interviews of almost all the informants no matter they belong to lower class, middle class or upper class. In the "Government actions regarding COVID-19" pro-government upper and middle class media users appreciated the actions of government while anti-government upper and middle class media users and most of the lower class users were of the view that government's actions are not satisfactory. Government needs to respond to this pandemic in smarter ways.

Moreover it was observed that though there was a difference of usage patterns among people of upper and middle socio-economic backgrounds but as they were spending time on social media so even if they are not using media for longer hours they were using media smartly. This way they were getting quality and comprehensive information even if they were spending less time on media.

People of lower socio-economic background were using very little time on social media due to the lack of internet availability. People were staying at home they were deprived of the internet they used to have at their work place. To use personal mobile data is expensive and people from lower socioeconomic status consider it wastage of money to buy mobile data. So the information they were having mostly based on TV news, newspapers or peer group.

The results of the study concluded that media is definitely cultivating fear among people of upper and middle socio-economic backgrounds as they were spending lots of time on media while people of lower class were not frightened of the virus because their media consumption time is far less as compared to the other two socio-economic groups. Social media's role in the cultivation of fear among users is the most devastating as social media is a platform where everyone can share their views. Few people have the ability to distinguish between information from authentic sources and personal information shared by other users that is why people of different socio-economic backgrounds who used media for longer periods of time were more afraid of the corona virus.

\section{References}

Ahorsu, D. K., Lin, C. Y., Imani, V., Saffari, M., Griffiths, M. D., \& Pakpour, A. H. (2020). The Fear of COVID-19 Scale: Development and Initial Validation. International journal of mental health and 


\section{Review of Economics and Development Studies, Vol. 6 (2) 2020, 217-228}

addiction, 1-9.

Ait Addi, R., Benksim, A., Amine, M., \& Cherkaoui, M. (2020). COVID-19 outbreak and perspective in Morocco. Electron J Gen Med. 2020; 17 (4): em204.

Alcabes, P. (2009) Dread: How Fear and Fantasy Have Fueled Epidemics from the Black Death to the Avian Flu. New York: Public Affairs Books

Altheide, D. and Michalowski, R. (1999) Fear in the news: A discourse of control, The Sociological Quarterly, 40, 3, 475-503

Altheide, D. L. (2002). Creating fear: News and the construction of crisis. Transaction Publishers.

Amy B. Jordan (1992) Social class, temporal orientation, and mass media use within the family system, Critical Studies in Mass Communication, 9:4, 374-386, DOI: 10.1080/15295039209366840

Ball-Rokeach, S. J., \& DeFleur, M. L. (1976). A dependency model of mass-media effects. Communication Research, 3, 3-21. http://dx.doi.org/10.1177/009365027600300101

Berger, P. L., \& Luckmann, T. (1966). The social construction of reality: A treatise in the sociology of knowledge. New York: Anchor Books.

Bomlitz, L. and Brezis, M. (2008) Misrepresentation of health risks by mass media, Journal of Public Health, 30, 2: 202-4.

Charmaz, K. (2006). Constructing grounded theory. A practical guide through qualitative analysis. Thousand Oaks, CA: Sage Publications.

Cresswell, J.W. (1994). Research design: qualitative and quantitative approaches. Thousand Oaks, CA: Sage.

Davis, D., \& Baran, S. J. (2011). Mass Communication Theory: Foundations, Ferment, and Future. CENGAGE Learning.

Denzin, N. K. Lincoln, Y. (Eds.) (1994). Handbook of Qualitative Research. Thousand Oaks, CA: Sage.

Furedi, F. (2007). The only thing we have to fear is the 'culture of fear' itself. American Journal of Sociology, 32, 231-234. Retrieved from http://people.morrisville.edu/ reymers/readings/SOCl101/Culture\%20of\%20Fear\%20essay-2007-04-04.pdf

Garfin, D. R., Silver, R. C., \& Holman, E. A. (2020). The Novel Coronavirus (COVID-2019) Outbreak: Amplification of Public Health Consequences by Media Exposure. Health Psychology. http://dx.doi.org/10.1037/hea0000875

Gerbner, G. (1969). Toward 'cultural indicators': The analysis of mass mediated public message systems. AV Communication Review, 17(2), 137-148. doi: 10.1007/BFo2769102.

Gerbner, G. A. (1970). Cultural indicators: The case of violence in television drama. The Annals of the American Academy of Political and Social Science, 388, 69-81.

Gerbner, G. (1998). Cultivation analysis: An overview. Mass communication and society, 1(3-4), 175194. DOI: $10.1080 / 15205436.1998 .9677855$

Grupp, S. (2003). Political Implications Of A Discourse Of Fear; The Mass Mediated Discourse Of Fear In the Aftermath Of 9/11, unpublished paper: Berlin: 43

Hansen, K. F. (2009). Approaching doomsday: how SARS was presented in the Norwegian media. Journal of Risk Research, 12(3-4), 345-360.

Kvale, S. (1996). Interviewsan introduction to qualitative research interviewing. Thousand Oaks, CA: Sage.

Llewellyn, S. (2020). Covid-19: how to be careful with trust and expertise on social media. BMJ, 368.

Lofland, J \& Lofland, H. L. (1995). Typological Systems: Analyzing social settings,(Third edition). Belmont, Cal.: Wadsworth.

Mamun, M. A., \& Griffiths, M. D. (2020). First COVID-19 suicide case in Bangladesh due to fear of COVID-19 and xenophobia: possible suicide prevention strategies. Asian journal of psychiatry, 51, 102073.

Mesch, G. S., Schwirian, K. P., \& Kolobov, T. (2013). Attention to the media and worry over becoming 
infected: the case of the Swine Flu (H1N1) Epidemic of 2009. Sociology of health \& illness, 35(2), 325-331.

Rehman, A., Jingdong, L., \& Hussain, I. (2015). The province-wise literacy rate in Pakistan and its impact on the economy. Pacific Science Review B: Humanities and Social Sciences, 1(3), 140-144. https://doi.org/10.1016/j.psrb.2016.09.001

Rubin, H., \& Rubin, I. (1995). Qualitative interviewing: The art of hearing data. Thousand Oaks, CA: Sage

Setbon, M. and Raude, J. (2010) The 2009 pandemic H1N1 influenza vaccination in France: Who accepted to receive the vaccine and why? European Journal of Public Health, 20, 5, 490-4.

Shahzad, M. K., Zahid, A., ur Rashid, T., Rehan, M. A., Ali, M., \& Ahmad, M. (2017). Techno-economic feasibility analysis of a solar-biomass off grid system for the electrification of remote rural areas in Pakistan using HOMER software. Renewable energy, 106, 264-273. https://doi.org/10.1016/j.renene.2017.01.033

Shanahan, J., \& Morgan, M. (1999). Television and its viewers: Cultivation theory and research. $\begin{array}{llllll}\text { Cambridge university } & \text { press. } & \text { P. } & \text { 4. Retrieved }\end{array}$ https://www.researchgate.net/profile/James_Shanahan3/publication/43128088_Television_and_Its_Viewe rs_Cultivation_Theory_and_Research/links/09e4151237ff0c0f14000000.pdf

Strauss, A., \& Corbin, J. (1998). Basics of qualitative research: Techniques and procedures for developing grounded theory (2nd ed.). Thousand Oaks, CA: Sage.

Van den Bulck, J., \& Custers, K. (2009). Television exposure is related to fear of avian flu, an ecological study across 23 member states of the European Union. The European Journal of Public Health, 19(4), 370-374.

Wang, X. (2009). Seeking channels for engagement: media use and political communication by China's rising middle class. China: An International Journal, 7(01), 31-56.

Yardi, S., \& Bruckman, A. (2012, May). Income, race, and class: exploring socioeconomic differences in family technology use. In Proceedings of the SIGCHI Conference on Human Factors in Computing Systems (pp. 3041-3050). 